нового, раніше небувалого.

\section{СПИСОК ДЖЕРЕЛ}

1. Арутюнова А. Б. Совершенствование профессиональной подготовки эстрадного исполнителя (вокалиста) на современном этапе. Дис. канд. пед. наук : 13.00.02. Белгородск. ин-т искусств и культуры. М., 2013.

2. Казанцева Л. П. Понятие исполнительской интерпретации. Музыкальное содержание: наука и педагогика. Уфа: РИЦ УГАИ, 2004, с. 149-156.

3. Коллиер Дж.Л. Дюк Эллингтон. Пер. с англ.; Предисл. А. В. Медведева. М. : Радуга, 1991.

4. Конен В. Рождение джаза. М. : Искусство, 1984.

5. Мальцев С. М. О психологии музыкальной импровизации. М. : Музыка.

6. Олексюк, О. М. Музична педагогіка. навч. посіб. К.: Київ, ун-т ім. Б. Грінченка, 2012.

7. Степурко О. М. Скет импровизация. Камертон, 2006

8. Stoloff B. Vocal improvisation (Techniques scat). New York: Gerard and Sarzin Publishing Co., 1972. (in English).

\section{REFERENCES}

1. Arutyunova A. B. (2013). Sovershenstvovanie professionalnoy podgotovki estradnogo ispolnitelya (vokalista) na sovremennom etape. [Sovershenstvovanie professional training of a pop singer (vocalist) at the present stage]. Moscow.

2. Collier, J. L. (1991). Duke Ellington. Pereklad A. V. Medvedyevoyi. [Duke Ellington.
Translated by A. V. Medvedeva]. Moscow.

3. Kazantseva, L. P. (2004). Ponyatie ispolnitelskoy interpretatsii. [The concept of performing interpretation]. Ufa.

4. Konen, V. (1984). Rozhdenie dzhaza. [The birth of jazz]. Moscow.

5. Maltsev, S. M. (1991). O psihologii muzyikalnoy improvizatsii. [On the psychology of musical improvisation]. Moscow.

6. Oleksiuk, O. M. (2012). Muzychna pedahohika. [Music pedagogy]. Kyiv.

7. Stepurko, O. M. (2006). Skat-improvizatsiya. [Scat improvisation]. Moscow.

8. Stoloff, B. (1972). Vokal'na improvizatsiya. [Vocal improvisation]. New York.

\section{ВІДОМОСТІ ПРО АВТОРА} МИРОШНИЧЕНКО Валерій Миколайович - аспірант Київського університету імені Бориса Грінченка.

Наукові інтереси: удосконалення освітнього процесу в закладах вищої мистецької освіти шляхом розв'язання проблем навчання джазової імпровізації майбутніх артистів-вокалістів.

\section{INFORMATION ABOUT THE AUTHOR}

MYROSHNYCHENKO Valerii Mykolaiovych - Student of Borys Grinchenko Kyiv University.

Circle of scientific interests: improvement of educational process in institutions of higher art education by settling the issues of teaching jazz improvisation to future vocal artists.

Стаття надійшла до редакиії 17.02.2021 p

UDK 378.11

DOI: 10.36550/2415-7988-2021-1-192-193-199

ROYTENKO Nina Oleksiivna senior lecturer at the Department of Music Theory and Vocal Southukrainian national K. D. Ushinsky Pedagogical University ORCID:https://orcid.org/0000-0001-9464-3661 e-mail: nroitenko@gmail.com

\title{
CREATION OF AN INDIVIDUALIZED INFORMATION AND EDUCATIONAL ENVIRONMENT IN THE VOCAL CLASS
}

Formulation and justification of the urgency of the problem. One of the main tasks of education today is the development of personality and individuality of the student, his abilities, independence and independent selfactivity. The education system is designed to form a person who can exist in changing social and economic conditions and actively influence the existing reality, transforming it for the better.

The essence of individual and personalityoriented education - to teach a person to choose the right direction of one's educational trajectory and maximize the use of various resources to build individual educational activities. It is the student and his parents who become customers for their education. This situation requires new approaches and principles of learning. The nature of the interaction between the teacher and the student must also become new.

The use of new effective teaching methods is an integral part of the modern development of education and pedagogical science. Much attention is paid to research and experimental activities of teachers and in one of the main areas of such activities is the use of information and communication technologies and the Internet. This is due to the fact that scientific and technological progress is accelerating every day, 
automated systems, software devices, robots, etc. are being introduced into production everywhere. All this poses a serious task for education and pedagogy - to combine the learning process and the use of new technologies, to train workers who will be ready to work in an informative society.

The main principle of education is not so much the transfer of knowledge to students, as the development of their learning and cognitive activity. Thus, the student is the subject of his own education. The transition from education to self-education, self-upbringing involves a change in the nature of the learner, when he becomes an active discoverer of knowledge, personal experience, responsible for his activities and its results.

The success of this approach is possible through the individualization of the educational process.

Analysis of recent research and publications. The development of personality has a long educational tradition, which originates from the research of Ya. A. Comenski, Zh-Zh. Rousseau, I. G. Pestalozzi, I. Disterverg, K. D. Ushinsky and other founders of classical pedagogy. These works emphasize the importance of using in education the ability to learn independently by oneself throughout life, using the opportunities of the world and external circumstances.

The problem of the learning environment and development is reflected in various versions of the concept of pragmatically oriented pedagogy («Learning by doing») by J. Dewey. It was he who called to make the teacher a «facilitator of teaching», to teach the child to think, to become his guide and helper, and not to remain only in the role of mentor [1].

In modern scientific research, the problem of organizing the educational environment is relevant and is of particular importance for educational processes. In the works of G. Yu. Belyaev, V. A. Kozyrev, N. B. Krylov, V. A. Levin and others, the concept of the content of the educational environment is substantiated, its structural components and parameters are determined. The environment within the system approach is considered as a set of all objects, the dynamics of the properties of which affect the system, as well as objects whose properties change as a result of the system.

Ideas for the development of the educational environment have been developed in detail in the studies of many psychologists and teachers (G. Kovalev, V. Lebedeva, O. Orlov, V. Panov, A. Petrovsky, V. Rubtsov, N. Reznik, S. Pozdnyakov, M. Bolshakov, T Weaver,
B. Elkonin, V. Yasvin, etc.). The problem of the use of information and educational environments was studied by I. Robert, M. Zhaldak, I. Bogdanova, Y. Trius, N. Morse, O. Spivakovsky, V. Sharko.

The purpose of the article is to determine the features of the formation of the educational environment in the transition from the classical form of learning to distance learning during individual vocal lessons.

The main material of the study. In our society, regardless of the type of activity, everyone owns and operates information, using it, solves certain problems. The value of information grows daily, experience is gained, new literature, ideas, research, etc. appear. This confirms the fact that with the increase in the amount of information the level of informatization of society increases. In general, it contributes to the formation of an information environment that affects the development of each individual and humanity as a whole.

The information environment consists of a large number of information objects and connections between them, means and technologies of collection, accumulation and transmission, processing and production, dissemination of information, knowledge and organizational and legal structures, which are the main support of information processes. The environment and society are interdependent. As practice shows, the level and quality of the information environment affects the people who have contact with it, ie a quality environment can significantly improve the intellectual level of the individual in all areas, including education, and vice versa.

There are areas that affect the formation and restructuring of the information environment:

- mathematization and informatization;

- intellectualization of activity (with the help of hardware and software is management, communication, independent work with knowledge, etc.);

- integration processes (combination of information and operational technologies in order to obtain a «technological breakthrough»);

- improving the infrastructure of the education system and management mechanisms (allows easy use of information resources, to provide methodological support for classes, to strengthen ties between separate structures of the educational system, to conduct all the «paper» work of the teaching staff).

The use of information and educational environment can significantly develop the intellectual potential of the university, improve and enhance the forms and content of 
educational activities and the educational process. With the introduction of distance learning, the question of advantages and disadvantages is constantly discussed in the educational environment, finding their supporters and opponents. However, new technologies are gradually and successfully introduced into the educational process, but in the artistic and creative direction, especially in the process of learning vocals, they are almost undeveloped and in little demand.

The basis of vocal and choral skills, of course, is the process of vocal and choral training. The main task of vocal and choral training is the education of professional skills and abilities of singing in the choir, as well as the management of the choir on the basis of mastering the methods of working with the choir; use of didactic principles and knowledge of the psychophysiological process that occurs during singing.

Vocal training is a complex process that combines musicological, interpretive-research, psychological-pedagogical and organizational aspects, which are the subject of research of many scientists. In the system of higher music and pedagogical education, vocal and choral training of future music teachers consists of a series of interrelated disciplines that are part of professional training: conducting, choir class and choir work workshop, choral studies, academic vocals, choral arrangement.

The task of the future music teacher - a pupil of a pedagogical school - is not only to have their own voice, but also to educate the voice of children, the ability to feel the processes occurring in their vocal apparatus during phonation. The future music teacher must prepare for the realization of these qualities in all classes, in particular, choral, conducting, solfeggio, choral studies, vocals. One of the tasks of professional training of students is the formation of a singing voice, as singing is the main means of their active involvement in the world of musical art and one of the main types of musical activities in music lessons in secondary school.

Teaching a child to sing correctly is the most difficult part of a teacher's job, as it is a «living» instrument - the voice. Therefore, the main task of vocal and choral training of future music teachers is to have your own voice at a high level of awareness of the technology of the singing process. After all, the teacher's voice is not only his main instrument, but also a powerful factor in directly influencing the formation of children's voices: as the teacher sings, so do the students. He must be familiar with the theory and methods of teaching vocals, be able to analyze the state of the student body and individual singers, to find methodically correct techniques and means of developing the voice of students. One of the tasks of acquiring vocal and choral skills in the process of professional training of future music teachers is the expressive performance of vocal works, as it is the main means of their active involvement in the world of vocal and choral art. In musicpedagogical science, the formation of vocal and choral skills is the most pressing problem, because the formation of this system is one of the goals of music education.

Teachers-practitioners offered different methods of vocal and choral training:

- method of combining absolute and relative solmization - O. Kastalsky;

- methods of phase learning of a choral work - P. Chesnokov;

- methods of register-timbre system V. Orlov;

- method of dynamic and timbre interaction of choir voices - G. Dmitrevsky;

- technique of intonation of intervals $-\mathrm{K}$. Pigrov;

- method of breathing process O. Egorov;

- methods of vocal training based on song repertoire $-\mathrm{M}$. Demyanov;

- methods of complex music and singing education - V. Ogorodnov;

- methods of improving the singing voice in terms of elemental formation of means of activity, skills and abilities - D. Lokshin;

- methods of acquiring reading skills of various rhythmic and pitch combinations as a means of developing musical abilities, thanks to which singing becomes an art that cultivates aesthetic tastes and feelings of beauty K. Stetsenko;

- methods of using folklore V. Verkhovynets, F. Kolessa;

- method of interconnection of different types of musical activity, development of musical and creative abilities and artistic and figurative thinking - M. Leontovych;

- methods of development of vocalintonation hearing - M. Mukhin;

- methods of mastering technical and artistically expressive means for the transmission of thoughts, feelings, which are embedded in the works - V. Sokolov.

Individual form of education has remained an integral part of the training of future vocalists, although in the information network today you can find many offers from private teachers, from playing the instrument to vocal training or conducting. This suggests that contact via computer telecommunications between the 
teacher and the student in this form of learning can be quite popular. The complexity and individuality of the singing instrument, the versatility of all its parts, the peculiarities of volitional control of the phonation process, the need to use associations, the dependence on the natural talent of the student and his psyche, the attitude to the future profession - all this implies the need for many.

However, it can be seen that some forms of learning can be implemented remotely, while others do not. For example, there is no doubt about the possibility of using distance learning in the teaching of such disciplines as theory, music history, development of computer music technology, as well as online group and individual webinars (convenient learning platform), master classes, forum discussions, performance of test tasks, etc.All this opens wide opportunities for distance learning. The educational environment based on the principles of personality-oriented education and development can be, in our opinion, a set of conditions, influences, factors and opportunities for the development of cognitive interest, because it involves the development of selectivity - (emotional attractiveness and personal significance), evaluation of one'sachievements), actualization of meaning (fundamental interest), development of subjective position, reflection, etc. Many events and factors interact in the environment, creating a kind of space of «activity interactions» - for example, individual vocal lessons create a special climate, «aura», where there is an energetic interaction between the participants of the creative process - the student, the teacher and the accompanist. Between the teacher and the student there is an exchange of feelings at the level of the subconscious, personal charisma of both, which is a pedagogical means of developing cognitive interest as a necessary condition for the formation of personality. The most important role in vocal creativity is played by intonation, which is able to give different meanings to the same phrase; facial expressions, postures, looks, and gestures can enhance and complement the meaning of each vocal phrase. One of the defining features of the musical creative process can be considered the ability to move a person to another world - the world of feelings and sensations.

In our opinion, music-pedagogical education, first of all, should solve the problem of revealing the meaning of the future teachermusician'sexistence in the world of art through understanding the nature and ways of its interaction with this world. That is why it is important not only to ensure the development of professional knowledge and skills, but also the development of value consciousness of music teachers, an integral part of which should be the presence of cognitive interest, ability to perceive, accept and assimilate values of other cultures [3].

The value orientations of a person determine his emotional and psychological state, satisfaction and fullness of life, and the value system regulates behavior and activity, determines the motivational sphere, personality orientation, willingness to be guided by these values in professional activities.

The high level of formation of value orientations allows the future teacher of music art to selectively treat the surrounding phenomena and objects, adequately perceive and evaluate their subjective and objective significance, i.e. to navigate in the world of material, musical and spiritual culture. It can be concluded that the organization of the educational environment focused on values, interests of the subject of study, should be aimed not at forming a personality with given properties, but at creating conditions for full manifestation and development of personality functions as the subject of educational process.

But the variability of the modern system of higher music and pedagogical education, the focus on personality-oriented and innovative learning now leads to the transformation of modern educational institutions into entities that develop the education system. Achieving such a transition should be based on providing conditions for the introduction of new innovative technologies in order to further revealing the creative potential of music students.

Radical changes in the current sociocultural situation give rise to new trends in educational processes, forcing us to look for new ways in the field of innovative technologies. Intensive formation of intellectual intercultural space, development of ethnic communities and other cultures makes new demands on professional education. Such radical changes taking place in the world, persistently dictate the need to reorient society towards the reproduction of culture and raise questions about the role of a man in its context [5].

In the new conditions of distance learning significantly changes and complicates the role of the teacher, because at the contactless interaction between the teacher and the student there are some difficulties, for example: limited opportunities for group work in individual vocal lessons, i.e. a group of 3 participants - a student, an accompanist, a teacher - feels some difficulties of a specific nature of vocal training 
(discrepancy of sound duration, loss of timbre colors of voice due to imperfection of technical means); the absence of the human factor, which is simply necessary.In addition, there are no interpersonal relationships in which students are in great need, communication is destroyed. But it should also be noted the positive qualities of distance learning, for example, a teacher who participates in distance learning, has the opportunity to realize his talent in the production of methodical materials. However, the degree of perception of this material depends on how interested the student will be in the desire to obtain a positive result, i.e. a large role is given to the student's independent work, his desire for self-knowledge and creative approach to learning.

We consider the use of technical teaching aids with their subsequent introduction into pedagogical practice to be relevant components in the content of vocal training of music students during distance education. Modern requirements for professional skills, in particular, vocal and choral, require new knowledge in the field of information technology. In this regard, the modern specialist must have a sound idea of the possibilities, trends and prospects of further technological society; to be acquainted with promising technologies in the field of vocal art; to use electronic and musical technologies in the performing and pedagogical process of vocal and choral groups; to form not only own information literacy, but also each student.

In the second half of the twentieth century, a new concept of «microphone culture» emerged in vocal and choral activities. According to $\mathrm{V}$. Goncharov, it contains the following components: 1) the use of microphones and amplifying equipment; 2) performance on the «phonogram» accompanied by microphones; 3 ) interaction with the media (radio, television).

In the content of vocal and choral skills of future music teachers, it is important to obtain special knowledge, skills and abilities in the field of sound amplification and sound recording.

Undoubtedly, an important factor is the solution of such issues in the process of performing vocal and choral work, namely:

- determination in the process of performing or recording the acoustic features of a concert hall or studio;

- location of the choir and place of microphones;

- conditions for maintaining or changing the choral balance;

- the degree of use of sound processing devices - equalizer (tone corrector), reverberator (volume, echo), etc.
One of the important issues for sound balance correction is the correct installation of microphones. It is implied that the most famous is the following:

- short-range microphones (from 0.3 to 2-3 meters) determine the legibility of the musicalpoetic text and the vocal-timbre features of the performers;

- mid-range microphones (from 3 meters onwards) combine sound;

- long-range microphones (from 14 meters and more) specify the result in the conditions of the appearance of the natural effect of «echo».

Note the need for knowledge about the technical characteristics of microphones that determine their sensitivity, frequency-timbre selectivity and range. For example, short-range microphones, so-called «solo» or «narrow», are more receptive to singers who are right next to them and need more attention to balance the dynamic balance between performers. At the same time, studio microphones with a wide range of action, the so-called «broadband», are more convenient for maintaining a dynamic balance in the choir in recording or performance with amplifying equipment. Thus, knowledge of modern technical means allows a music teacher to acquire professional skills of vocal and choral skills.

In the process of research we analyzed the following technical means of learning: keyboard synthesizer, multimedia personal computer, MIDI, laser disk (CD-DA), mini-disk deck (MD-DA), radio karaoke microphone «Lead singer», system video karaoke «LG».

Thus, obtaining special knowledge and skills in the field of technical teaching aids is an important component in the content of vocal and choral skills of future music teachers, the level of which is determined not only in the study of music, but also as concert performances.

Let us now consider one of the important conditions in the content of the process of formation of vocal and choral skills of future music teachers - visual comparison, comparison of their own activities with the system of requirements for professional action. To do this, in the process of professional training is useful to use modern multimedia information technology.

Multimedia tools allow students to provide the necessary sound and visual methodological information, which is the basis for improving vocal and choral skills. If we compare the capabilities of multimedia with analog audio and video media, we will note the high integration of the system, the development of logical internal connections and the high strength of individual media. Interaction, free interpretation and 
communication should be factors in the use of multimedia.

An important didactic tool is the combination of television and computer systems. The use of static and dynamic video in multimedia makes it possible to record vocal and choral performance in combination with rhythmic movements with all sound and visual components, to save unlimited time and to play repeatedly if necessary.

The didactic value of multimedia in the formation of vocal and choral skills of future music teachers is not only in the accumulation and transformation of audiovisual characteristics of the performance process, but also for selfcontrol, self-assessment of the whole performance process as a whole and individual episodes.

The use of information with the use of multimedia requires the student to mobilize assessment and analytical skills, as well as the ability to use them - as an assessment of their educational work, and as a perception of all musical and artistic trends and pedagogical phenomena.

Based on our own experience, we can note that in the transition to distance learning there was a noticeable creative decline in the process of studying for students, especially in the initial period. This can be explained by the instinctive desire for support from the teacher, the expectation of energetic emotional message in their direction, as well as imperfect technical providing [7].

Conclusions and prospects for further researches of directions. Summarizing all the above mentioned, it can be noted that in the system of information and educational environment has revealed the inadequacy of existing approaches to the formation of professional competence of teachers in the information and educational environment of higher education; there is a certain underdevelopment in theory and practice; there are no system developments that would be used in the educational process.

However, the information and educational environment changes the content of education, activates traditional and stimulates the development of new forms of activity of students and teachers, and at the same time the environment itself develops through creative processes. Thus, the modification of the traditional process of education into learning in a virtual environment requires a radical revision of the requirements for the teacher and the system of his training.

\section{СПИСОК ДЖЕРЕЛ}

1. Андреев А. А. Некоторые проблемы педагогики в современной информационнообразовательной среде / А. А. Андреев // Инновация в образовании. 2004 № 6. С. 98-112.

2. Гурниковская Р. Ю. Информационнообразовательная среда общенаучной подготовки студентов гуманитарных специальностей: диссертация...канд. пед. наук: 13.00. 08 / Р. Ю. Гурниковская. Ростов - на Дону, 2006. $193 \mathrm{c}$.

3. Горбунова И. Б. Интерактивные сетевые технологии обучения музыке и музыкальнокомпьютерные технологии / И. Б. Горбунова // Мир науки, культуры, образования. 2016. С. 126131.

4. Кязимов К. Г. Инновационная образовательная среда вуза как условие подготовки квалифицированных специалистов / К. Г. Кязимов // Профессиональное образование в современном мире. 2015. № 5. С. 976-984.

5. Лысенко А. В. Психолого-педагогические условия формирования профессиональноценностных ориентаций будущего учителя музыки: дис. ...канд. пед. наук: 13.00.08. / А. В. Лысенко. Майкоп, 2005. 203 с.

6. Матолыгина Н. В., Руглова Л. В. О педагогическом авторитете преподавателя высшей школы на современном этапе развития / Н. В. Матолыгина, Л. В. Руглова // « Мир науки», 2017. C. $78-98$.

7. Стародубцев В. А. Создание персональной образовательной среды преподавателя вуза / В. А. Стародубцев Томск. 2012. 124 с.

\section{REFERENCES}

1. Andreyev, A. A. (2004). Nekotoryye problem pedagogiki $v$ sovremennoy informatsionnoobrazovatel'noy srede. [Some problems of pedagogy in the modern information and educational environment]. Moscow.

2. Gurnikovskaya, R. YU. (2006). Informatsionno-obrazovatel'naya sreda obshchenauchnoy podgotovki studentov gumanitarnykh spetsial'nostey. [Information and educational environment of general scientific training of students of humanitarian specialties]. Rostov.

3. Gorbunova, I. B. (2016). Interaktivny yesetevyye tekhnologii obucheniya muzyke $i$ muzykal'no-komp'yuternyye tekhnologii. [Interactive network technologies for teaching music and musiccomputer technologies]. Moscow.

4. Kyazimov, K. G. (2015). Innovatsionnaya obrazovatel'naya sreda vuza kak usloviye podgotovki kvalifitsirovannykh spetsialistov. [The innovative educational environment of the university as a condition for the training of qualified specialists]. $\mathrm{SPb}$.

5. Lysenko, A. V. (2005). Psikhologopedagogicheskiye usloviya formirovaniya professional'no-tsennostnykh oriyentatsiy budushchego uchitelya muzyki. [Psychological and pedagogical conditions for the formation of professional and value orientations of the future music teacher]. Maikop.

6. Matolygina, N. V., Ruglova, L. V. (2017). $O$ pedagogicheskom avtoritete prepodavatelya vysshey shkoly na sovremennom etape razvitiya. [On the 
pedagogical authority of a teacher of higher education at the present stage of development]. Kharkov.

7. Starodubtsev, V. A. (2012). Sozdaniye personal'noy obrazovatel'noy sredy prepodavatelya vuza. [Creating a personal educational environment for a university teacher]. Tomsk.

\section{ВІДОМОСТІ ПРО АВТОРА}

РОЙТЕНКО Ніна Олексї̈вна - старший

викладач кафедри теорії музики та вокалу Південноукраїнського національного педагогічного університету імені К. Д. Ушинського.

Наукові інтереси: професійна підготовка майбутнього вчителя музичного мистецтва

\section{INFORMATION ABOUT THE AUTHOR}

ROYTENKO Nina Oleksiivna - Senior Lecturer of the Department of Music Theory and Vocal Theory of K. D. Ushinsky Southukrainian National Pedagogical University.

Circle of scientific interests: professional training of future music teachers.

Стаття надійшла до редакиії 15.02.2021 p.
UDC 881.378

DOI: $10.36550 / 2415-7988-2021-1-192-199-203$
SARNOVSKA Nataliia Ivanivna Lecturer, Foreign Languages Department Kyiv National University of Culture and Arts ORCID:https://orcid.org/0000-0001-7278-5183 e-mail: nat_sarnovskaya@ukr.net

ANTONIVSKA Maryna Oleksandrivna -

Lecturer, Foreign Languages Department Kyiv National University of Culture and Arts ORCID:https://orcid.org/0000-0002-4451-3735 e-mail: antonivska_maryna@ukr.net

\section{ORGANIZING OF DISTANCE FOREIGN LANGUAGES TEACHING IN HIGHER EDUCATION ESTABLISHMENTS IN CURRENT CONDITIONS: PROBLEMS, METHODS, TECHNOLOGIES}

Formulation and justification of the urgency of the problem. At the moment, due to the current situation in the country and in the world, the relevance of distance learning has become undeniable. This training format implies the process of interaction between the teacher and the student at a distance with the preservation of all components of training (goals, content, methods, organizational forms) and with the use of specific technical means (Internet technologies or other interactive environments). This article examines the forms and methods of distance learning and their integration into teaching a foreign language in higher educational establishments from the point of view of the advantages and disadvantages of their use in foreign language lessons.

Analysis of recent research and publications. Theoretical and practical aspects of distance learning have been considered in studies by both foreign and domestic scientists: J. E. Adams, F. Bodendorf, H. Dichanz, G. Hoppe, J. Kettunen, A. A. Andreeva, V. Yu. Vashchenko, K. R. Kolos, V. O. Kukleva.

There are many approaches and interpretations of the term «distance learning». For example, according to the Concept of
Distance Education Development in Ukraine of December 20, 2000, «distance learning is a set of technologies that deliver the main amount of material to 7 students, or any learners, and provide interactive interaction between students and teachers during the educational process, the method of providing students to work independently» [5]. According to V. Rybalko, distance education is important because it is a specific organization of the educational and pedagogical process, which is based on the use of distance, information and telecommunications technologies [7]. The author of the monograph «Theory and methods of informatization of education», I. V. Robert defines the term «distance learning» as a process of interactive interaction between student, teacher and interactive source of information resource, during which the transfer of knowledge, skills and abilities carried out in conditions of ICT implementation [9]. According to A. V. Khutorskyi, distance learning means learning, during which the participants in the process, i.e. the subjects of learning are at a distance and carry out the educational process by using the means of telecommunications [10].

The purpose of the article is to consider 